\title{
Potential Use of the Caspian Sea Water for Supplementary Irrigation in Northern Iran
}

\author{
H. Ghadiri ${ }^{\mathrm{a}}$, I. Dordipour ${ }^{\mathrm{b}}$, M. Bybordi ${ }^{\mathrm{c}}$ and M. J. Malakouti ${ }^{\mathrm{c}}$
}

${ }^{a}$ Faculty of Environmental Sciences, Griffith University, Nathan, Queensland 4111, Australia,

${ }^{\mathrm{b}}$ Gorgan University, Gorgan, Iran;

${ }^{\mathrm{c}}$ Soil and Water Research Institute of Iran, North Kargar, Tehran, Iran.

Corresponding author: H. Ghadiri; Phone: +61 7 38755175. Fax: +61 73875 7459,

E-mail: $\underline{\text { H.Ghadiri@griffith.edu.au }}$

\begin{abstract}
Iran's groundwater resources have been over-exploited, often at the expense of deteriorating both water and land quality and there is limited room for expanding irrigation agriculture. Thus the possible use of Caspian Sea water, whose salinity is well below that of the open seas, for supplementary irrigation has some appeal. The impact of irrigation with diluted Caspian Sea water on the growth and yield of barley and on the characteristics of soil was investigated in field plots and in pot experiments during the 2001-2002 growing season. Three irrigation regimes of well water alone $\left(\mathrm{I}_{0}\right)$; Caspian Sea water diluted with well water and used at the time of plants' stem elongation $\left(I_{1}\right)$, and the same diluted sea water used at the time of plants' ear formation $\left(I_{2}\right)$. A rainfed treatment was also added to the field experiments. The results of both pot and field experiments show that a 1:1 mixture of Caspian Sea and well water can be used for irrigation without a significant reduction in the growth and yield of barley, provided that it is not applied earlier than the time of ear formation. This would amount to a significantly reduced demand on the limited ground water resources of the region for agricultural use. However, when this mixture was applied at the earlier time of stem elongation, significant yield reduction occurred. All other growth components of barley plants were also adversely affected by this early application of diluted sea water. Soil analysis after harvest showed that the EC of its saturation
\end{abstract}


extract had increased significantly in both seawater treatments. This may suggest that the mixing of sea and ground waters at rates used in these experiments may not be sustainable over a long period of time and soil salinization may occur unless soils are of light textured types and sufficient good quality fresh water or winter rain is available to lower the salinity of soil between successive crops. Further research for the determination of a suitable Leaching Ratio (LR) to stabilize soil salinity are in progress.

Keywords: Sea water, saline water, irrigation, salinity, groundwater, Caspian Sea

\section{Introduction}

Iran's winter-dominated rainfall pattern is such that rainfed agriculture is confine to the costal regions of the Caspian Sea in the north of the country. Irrigation agriculture is by far the most prevalent form of agricultural throughout the country. Using the landscape configuration and good engineering and hydrological skills, early settlers of Persian plateau invented the "Ghanat" system of irrigation through which free flowing groundwater provided them with an abundance of good quality water for irrigation which made Iran the largest irrigation agriculture country in the Middle East. Over-exploitation of ground-water in recent years, mostly though digging wells and pumping the water out, has lowered the ground-water levels rendering many thousands of Ghanats dry and in ruin. At the same time a rapid increase in the population of Iran during the past two decades has significantly increased the country's need for water, food and fibre and has put its land and water resources under severe stress. Freshwater resources of the country, both surface and ground water, has been over-exploited, often at the expense of deteriorating water and land quality. With limited room for expanding irrigation agriculture due to the lack of extra capacity in the country's freshwater resources, the possible use of Caspian Sea water, whose salinity is well below that of the open seas and oceans, has some appeal (Dordipour 2000). As shown in Table 1, the Caspian Sea water is also lower in $\mathrm{Cl}^{-1}$ and $\mathrm{Na}^{+1}$ and higher in $\mathrm{Ca}^{+2}$ and 
$1 \mathrm{SO}^{-2}$ contents than the water from open seas or oceans, which make it less harmful to soils'

2 physical and chemical health.

Saline water was previously considered unusable for irrigation but new research during the past two decades has helped bringing into practice some large irrigation schemes which depend on saline water (Hamdy et al.1993; Beltran 1999; Qadir et al. 2001 ). However, with its potential hazard of increasing land and ground-water salinity as well as possible deterioration of soil physical, chemical and biological characteristics, the issue needs to be thoroughly researched.

The sustainability of irrigated agriculture in arid and semi-arid regions depends on the maintenance of salt balance within the soil profile and disposal of shallow groundwater is often necessity. Saline drainage waters can be used for irrigation of certain crops and their use lessens drainage disposal requirements and water pollution (Rhoades et al.1980). Rhoades et al. (1989) further demonstrated a strategy for using saline and non-saline water in rotation, which caused no reduction in yield providing there was a good plant stands is already established.

Salinity generally affects the growth of plants by either ion excess or by water deficits in the expanded leaves (Greenway and Munns 1980). Water uptake is restricted by salinity due to the high osmotic potential in the soil and high concentrations of specific ions that may cause physiological disorders in the plant tissues (Feigin 1985) and reduce yields (Verma and Neue 1984). However, some crops such as wheat and barley can be tolerant of saline irrigation water, a property that can be enhanced by selection and breeding (Norlyn and Epstein 1982; Yazdani 1991). Research suggests that irrigation of barley with up to two-thirds seawater is feasible and may result in economically significant yields. This study examines growth and yield of barley in irrigated pot and field plot experiments using a mixture of Caspian Sea water and well water. The effect of the application of saline water on soil properties is also examined together with an assessment of overall water use and water use efficiencies in different irrigation regimes. 


\section{Materials and Methods}

\section{Pot experiments}

Barley (Hordeum vulgare L. cv. 'LB') was grown in a silty loam soil of the Agh-ghala series in plastic pots, $20-25 \mathrm{~cm}$ diameter and $31 \mathrm{~cm}$ height under a plastic green house (Fig 1). The soil was passed through a $5 \mathrm{~mm}$ sieve before being transferred into the pots. Irrigation water was provided from the Caspian Sea (carried by a tankers to the experimental site) and from a local well. The basic physio-chemical properties of the soil and water were determined with standard techniques (Richards 1954; Page et al. 1982; Sparks et al. 1996). Some chemical data for the irrigation waters and soils used in the trials are presented in Tables 2 and 3 respectively. The seawater was considerably more saline than the well water and salt concentrations varied slightly with season.

Drainage holes were made at the bottom of the pots and the pots were filled with $\sim 2 \mathrm{~cm}$ of gravel/sand to further improve drainage. Pots were packed with $16.95 \mathrm{~kg}$ air-dried soil in 5 x 5 cm uniformly compressed increments (Homaee 1999). The soil contained 12\%, 64\% and 24\% sand, silt and clay respectively and was classed as a silty loam texture. The bulk density and organic carbon content were $1400 \mathrm{~kg} \mathrm{~m}^{-3}$ and $0.59 \%$ respectively. The soil surface was then covered by a $10 \mathrm{~mm}$ layer of gravel to reduce evaporation and to avoid disturbance when applying irrigation water. A completely randomized factorial design was used with three irrigation and nine fertilizer regimes and application times and three replications. The three irrigation regimes were: $\left(\mathrm{I}_{0}\right)$ well water alone $(\mathrm{EC}=0.802 \mathrm{dS} / \mathrm{m}),\left(\mathrm{I}_{1}\right)$ Caspian Sea water $(\mathrm{EC}=$ $21.5 \mathrm{dS} / \mathrm{m}$ ), diluted with the well water at a 1:1 ratio and used at the stem elongation stage (Zadoks et al. 1974) and $\left(\mathrm{I}_{2}\right)$ same sea water/well water mixture as $\left(\mathrm{I}_{1}\right)$ but used at the ear formation (heading stage, Zadok’s code 70), respectively. The surface of each pot was divided 
into concentric circles, in which 40 barley seeds were sown on January 22, 2001. They were thinned to 20 plants after germination and full establishment of seedlings (Hassan et al. 1970).

Ten plants were used for measurement and sampling in the tillering and heading stages to determine the quantities of fresh and dry matter production and the 10 remaining plants used for yield and its components such as dry matter, nutrient contents, height, root length and so on. The pots were irrigated with well water for germination and establishment of seedlings. The irrigation then continued according to water requirement, until the respective irrigation treatments were applied. Three pots from each treatment were weighed before every irrigation and the required quantity of water was calculated from the difference between "pot capacity" (analogous to field capacity) and the actual weight minus plant weight, plus 30\% leaching fraction. Pot capacity was determined by adding excess water to pots with soil. The pots were then covered by plastic sheet to prevent evaporation and weighed over a few days until an equilibrium weight was attained. The irrigation cycle was adjusted according to the depletion of 50\% available water from the pot soil (Hassan et al. 1970; Bar-Tal et al. 1991; Marcelis and Van Hooijdonk 1999).

Fertilizer treatments consisted of all possible combinations of three levels of potassium and three levels of zinc whose results are reported elsewhere (Dordipour, 2004). Nitrogen was applied to all pots at the rate of $300 \mathrm{~kg} / \mathrm{ha}$ of urea (one third before planting, one third at the tillering and one third at the heading stage). Each treatment also received $75 \mathrm{~kg} \mathrm{P}_{2} \mathrm{O}_{5} / \mathrm{ha}$ as $\mathrm{NH}_{4} \mathrm{H}_{2} \mathrm{PO}_{4}$. At harvest, the plants were divided into tops (head, leaf and shoot) and roots (in two depth intervals of 0-10 and 10-20 cm) and their fresh and oven-dry weights were determined. After harvest, the soil of all pots was divided into two horizontal layers from 0-10 and 10-25 cm depths and analysed. Statistical analysis and mean comparisons test of main effects and interactions on the yield and its components, fresh and dry matter, soil and other parameters of plant were analysed by the SAS-ANOVA and SAS-MEANS procedures (SAS 1992). 


\section{Field Experiments}

3 Field experiments were carried out at Banavar Agricultural Research Station $15 \mathrm{~km}$ north-east of the city of Bandar Torkman and 5km from the Caspian Sea shore in the northern province of Golestan of Iran (latitude of $37^{\circ}, 10^{\prime} \mathrm{N}$ and the longitude of $54^{\circ}, 13^{\prime} \mathrm{E}$ ). Average annual temperature of the region is $17^{\circ} \mathrm{C}$ and annual rainfall and evapo-transpiration are $420 \mathrm{~mm}$ and $1636 \mathrm{~mm}$ respectively. Most of the rainfall occurs during the winter months of December to March, thus there is a sever water shortage during the growing season of crops. The region has around 26000 hectares of agricultural land, 5500 hectares of which is irrigated and the rest is rainfed. There are two rivers in the region but groundwater is the main source of irrigation water. The alluvial soil upon which field experiments were carried out is of silt-loam texture. Some of the physical and chemical characteristics of the soil are given in Table 3. The soil was ploughed in fall using conventional mouldboard plough but also tilled twice more prior to broadcasting barley seeds using disk plough. Plot size was 1 x $2 \mathrm{~m}$. A complete randomized block split plot factorial experiment with three replications was carried out during 2001-2002 growing season using four irrigation treatments $\left(\mathrm{I}_{\mathrm{r}}=\right.$ rainfed, no irrigation, $\mathrm{I}_{0}$, = irrigation with well water alone, $\mathrm{I}_{1}$ irrigation with a 1:1 mixture of well and sea waters starting at the time of stem elongation and $\mathrm{I}_{2}$ same as $\mathrm{I}_{1}$ but irrigation began at the time of ear formation). Eight fertiliser treatments where also included as secondary factors in the experiments whose results are reported elsewhere. There were 96 experimental plots arranged in a completely randomized form as shown in Fig 2. Three hundred barley seeds were sown in each plot in 5 rows $20 \mathrm{~cm}$ apart. One square metre in the centre of each plot was harvested for the measurement of yield and its components and the rest was used for sampling soil and plant for various other measurements carried out during the growing season.

\section{Measurements}


2 The following measurements were carried out for both pot and field experiments:

1. Measurement on barley plants included: plant height, head length, length of awns, peduncle length, kernel yield, yield components such as weight of 1000 kernel, number of kernel per head and the number of heads per $\mathrm{m}^{2}$, biomass (wet and dry), yield index, leaf area, water use efficiency, root weight.

2. Chemical analysis for the measurement of $\mathrm{Zn}, \mathrm{B}, \mathrm{Mg}, \mathrm{Ca}, \mathrm{Na}$, and $\mathrm{K}$ in leaves, stems, kernel and the entire plant were also carried out.

3. Measurements on soil samples included pH, EC, ESP, K, B, Cl and soluble and exchangeable $\mathrm{Na}, \mathrm{Ca}$ and $\mathrm{Mg}$.

4. Measurements on water samples were: $\mathrm{pH}, \mathrm{EC}, \mathrm{SAR}, \mathrm{Na}, \mathrm{Ca}, \mathrm{Mg}, \mathrm{K}, \mathrm{B}$, and $\mathrm{Cl}$.

\section{Results and Discussions}

\section{Effect of irrigation with saline water on the growth and yield of barley}

\section{Pot experiments}

As expected growth and yield of barley were highest in treatment $I_{0}$ where pure well water was used for irrigation (Table 4). Irrigation with seawater-well water mixture at stem elongation time $\left(\mathrm{I}_{1}\right)$ significantly reduced yield and most of the measured yield and growth components, but when applied at the later stage of ear formation $\left(\mathrm{I}_{2}\right)$ the yield and yield components' reductions were not significant (Table 4 and Fig 3). In $\mathrm{I}_{2}$ treatment yield, weight of 100 seeds and the number of heads per plant was slightly reduced compared to $\mathrm{I}_{0}$, but the number of seeds per head and spikelets were actually increased by 6.6 and $2.6 \%$ respectively. These results are in agreement with the findings of Francois et al. (1994) and Grieve et al. (1992) that salinity stress 
1 reduced the grain weight but not the number. Francois et al. (1994) also demonstrated that the

2 time or stage of salinity stress had a significant effect on grain-weight of wheat, which is the same as the results of this study on barley. Compared to $\mathrm{I}_{0}$ the number of sterile shoots in barley plants was increased by $68 \%$ and $17 \%$ and the number of unfilled heads by $11 \%$ and $12 \%$ for $\mathrm{I}_{1}$ and $\mathrm{I}_{2}$ respectively. Prolonged exposure of plants to saline water in $\mathrm{I}_{1}$ appears to have affected all aspects of plant growth and yield. The reduction in yield in treatment $\mathrm{I}_{1}$ appears to be the result of across the board reduction in yield and growth components, but a large increase in sterile shoots appears to have a major role in yield decline. Irrigation with seawater in the last stages of

Fig 4 shows the effect of irrigation regimes on the ratio of dry/fresh weights of leaf, head and shoot and areal biomass. This ratio for all four factors of leaf, head, shoot and areal biomass at harvest stage was higher than at the heading stage. With increasing soil salinity, induced by the extended use of seawater, this ratio for leaves and heads had a descending trend, but for the shoot and total areal biomass at harvest and for leaves, heads, shoots, and total areal biomass at heading stage showed a progressive trend, which indicates a water deficit in plant, resulting in less dry matter production and decline in yield. These results agree with those shown by Kwaon et al. (2000). The fact that total fresh weight was reduced more than total dry weight also suggests a water deficit at high salinity (Marcelis and Van Hooijdonk, 1999).

Visual observations of plant growth indicated that chlorosis, necrosis and margin/tip burns of leaves appeared at early stages of growth and developed as growth progressed. These injuries to plants increased as the salinity of water increased or as the period of plant exposure to saline water increased, with all the symptoms being more evident in $\mathrm{I}_{1}$ than $\mathrm{I}_{2}$. Similar salt-induced 
injuries to plants have also been reported for other cereal and non-cereal crops (Feigin, 1985;

Feigin et al., 1991; Hu, 1996).

The results also show that irrigation regimes significantly $(\mathrm{P}<0.01)$ affected the length of plants and those of the heads, peduncles and clavus. Irrigation with seawater, at stem elongation stage $\left(\mathrm{I}_{1}\right)$, decreased the overall length of the plants by $32 \%$, peduncle by $33 \%$, heads by $16 \%$ and clavus by $11 \%$. However when seawater was used at heading stage $\left(I_{2}\right)$, plant height was only reduced by $1 \%$ while the length of the heads, peduncles and clavus actually increased by $3 \%$, $0.4 \%$ and $13 \%$ respectively. These results are in accordance with those shown by Verma and Neue (1984). It can therefore, be concluded that the effects of irrigation with seawater at the lather stage of growth of barley $\left(\mathrm{I}_{2}\right)$ on the length parameters is negligible and sometimes beneficial and positive whereas, the adverse effects on all these factors are severe when irrigation with saline water starts early $\left(\mathrm{I}_{1}\right)$.

Statistical analysis of the experimental data showed that the effect of irrigation regimes on the fresh and dry weights of the roots were significant in the 0-10 and 10-25 cm and for the sum of the two depth intervals $(0-25 \mathrm{~cm})$ at $\mathrm{P}<0.01$ (Fig 5). Irrigation with seawater resulted in decline in the fresh and dry weights of roots for all depths at stem elongation and heading stages, but the decline was twice higher in $\mathrm{I}_{1}$ than $\mathrm{I}_{2}$. Such a high reduction in root production in $\mathrm{I}_{1}$ could have severely reduced plants' ability to uptake water and nutrients resulting in low growth and reduced yield of barley, as reported above. Plant root system was more concentrated in the 0-10 $\mathrm{cm}$ depth, which is the depth in which root growth was severely retarded.

The use of seawater caused a decline in the ratio of total fresh weight of roots to fresh weight of shoot (or aerial biomass) and also a decline in the ratio of total dry weight of roots to dry weight of shoots by $30 \%$ and $40 \%$ for $I_{1}$ and $I_{2}$ treatments respectively. This indicates that the use of 
seawater limited root growth of barley plants more than its shoots or areal biomass. These results appear to contradict those given by Helal and Mengel (1979) and Marcelis and Van Hooijdonk (1999) who have reported that salinity limits the growth of areal parts of the plants more than roots. In spite of applying a LF factor of 30\% in our pot experiments, soil salinity increased and resulted in salt accumulation in the root zone. This may have resulted in an undesirable drainage situation for plant roots thus adversely affecting their growth. However a large difference in root growth between $\mathrm{I}_{1}$ and $\mathrm{I}_{2}$ treatments does not support such argument.

\section{Field Experiments}

The results of field experiments closely followed those of pot experiments. Field results show that irrigation with diluted seawater at the time of stem elongation $\left(\mathrm{I}_{1}\right)$ and under rainfed conditions $\left(\mathrm{I}_{\mathrm{r}}\right)$ caused significant reduction in the barley yield and all the major yield components including, biomass and straw, number of heads and SW5000 (Fig 6). Number of seeds per head was not significantly affected by irrigation treatment and the difference between all treatments and control $\left(\mathrm{I}_{0}\right)$ remained small (Fig 5). The decrease in kernel weight amounted to 33\% and $59 \%$ respectively for $\mathrm{I}_{1}$ and $\mathrm{I}_{\mathrm{r}}$ treatments as compared with the control $\left(\mathrm{I}_{0}\right)$. On the other hand application of seawater at a later stage $\left(\mathrm{I}_{2}\right)$ did not cause significant differences with $\mathrm{I}_{0}$ with respect to all these parameters. Longer use of diluted seawater in $\mathrm{I}_{2}$ and also in rainfed treatment contributed to the reduction of the number of unfilled seeds per plant, which is mainly due to a significant reduction in the number of heads per plants in these two treatments. Similar results have been reported by Maas (1990), Bar-Tel (1991), O’Leary and El-Haddad (1994), Sharma (1996) and Tahir et al. (1997).

The results of field trial also clearly show that rainfed agriculture is not a viable option for the region. With the soil salinity already high and rainfall low, the plants suffer from both water 
stress and ion poisoning thus the lowest yield and yield components of $\mathrm{I}_{\mathrm{r}}$ treatments as shown in Fig 6. The results of both pot and field experiments suggest that supplementary irrigation with the diluted seawater after head formation is a viable option for barley crop in the region. It makes a significant saving in the consumption of the limited freshwater resources of the region without significantly reducing the yield of barley.

\section{Effect of irrigation on soil quality}

\section{Pot experiments}

The results of chemical analyses carried out on soil samples before and after the pot experiments are presented in Table 5. These results show that the concentration of sodium, calcium, magnesium and potassium in the top $10 \mathrm{~cm}$ of the soil irrigated with diluted seawater increased by more than 400, 17, 200 and 100 folds respectively during the growing season of barley. Also shown in Table 5 is a 60 and 30 folds increase in EC and SAR of saturated extract of soils during the same period and due to the irrigation with diluted seawater. The concentrations of all above cations are significantly lower in the 10-25 cm soil depth than 0-10 cm. EC and SAR are also lower in $10-25 \mathrm{~cm}$ depth by a factor of 10 compared to $\mathrm{I}_{0}$. These results indicate that the above reported reduction in yield and yield components of barley when irrigated with a diluted seawater early in the growing season $\left(\mathrm{I}_{1}\right)$ is largely due to the poisoning effect of high ion concentration in the soil solution in the root zone than water stress caused by osmotic potential of soil solution. Water stress appears to have a more immediate effect on the growth and yield of plants while ion poisoning needs a longer term exposure of the plant to such condition in order to have a significant impact on its growth and yield.

Mean comparison tests indicate that irrigation treatment $\mathrm{I}_{1}$ significantly increased soil salinity levels (Fig 7), particularly in its top $10 \mathrm{~cm}$. This indicated that the applied leaching fraction of 
$30 \%$ was not sufficient to prevent salt accumulation in the pots. Work on adequacy of LR is in progress.

\section{Field experiments}

Irrigation with 1:1 diluted seawater during the stem elongation period $\left(\mathrm{I}_{1}\right)$ and under rainfed condition $\left(\mathrm{I}_{\mathrm{r}}\right.$ ) significantly increased soil salinity, concentration of $\mathrm{Na}, \mathrm{Mg}$ and $\mathrm{Cl}$ ions and the SAR value of saturated extracts in the top $30 \mathrm{~cm}$ of soil profile (Fig 8). These changes were less pronounced deeper in the profile $(30-60 \mathrm{~cm})$. The increases in soil salinity and SAR in I2 treatment were insignificant. These field plot results confirm those obtained in pot experiments that irrigation with Caspian Sea could result in increased soil salinity if not used cautiously. It can only be used for supplementary irrigation of salt tolerant plants such as barley in light textured soils at the latter stages of plant growth.

Using the results of both pot and field plot experiments on soil salinity-plant yield interaction, the following equation was obtained relating barley yield (Y) to soil salinity.

$$
\mathrm{Y}=100-6.8(\mathrm{ECe}-7.7)
$$

This equation can be used to determine the EC level at which barley production becomes uneconomical in the Gorgan region of Iran.

\section{Conclusion}

Irrigation with a 1:1 mixture of Caspian Sea water and well water at the stem elongation stage of barley ( $\mathrm{I}_{1}$ treatment) adversely affected the yield and most growth and yield components of barley including aerial biomass, root and shoot growth and seed number and weight. This 
treatment also significantly increased soil salinity. However, irrigation with the same mixture at the heading stage ( $\mathrm{I}_{2}$ treatment), had an insignificant effect on the growth and yield of barley. Use of Caspian Sea water for supplementary irrigation is therefore a viable option and has the potential of substantially reducing the pressure on the limited groundwater resources of the region without a significant loss in barley production. However, the application of seawater-well water mixture whether applied early $\left(\mathrm{I}_{1}\right)$ or late $\left(\mathrm{I}_{2}\right)$ will result in an increased soil salinity which may cause problems for next crop’s germination and seedling growth as young plants are more susceptible to soil salinity. Long-term use of seawater for barley irrigation is only possible if the leaching of excessive salt from root zone is possible. Supplementary irrigation of barley with the Caspian Sea water-well water mixture can therefore be recommended light textured soils and only towards the last stages of barley growth, provided that low salinity fresh water or precipitation can be applied to lower soil salinity before the next crop is due to go in. The heading time of barley crop is precisely the time that fresh water resources of the region are very limited and the need for extra irrigation water is at its highest. With all its limitations and longterm adverse impacts on soils, irrigation with the Caspian Sea water can provide a much needed relief to farmers that their crops may otherwise fail.

\section{References}

Bar-Tal, A., Feigenbaum, S., Sparks, D. L., 1991. Potassium-Salinity I. Interactions in irrigated corn. Irrigation Science 12, 27-35.

Beltran, J.M. 1999. Irrigation with saline water: Benefits and environmental impacts. Agricultural Water Management 40, 183-194

Dordipour, I., 2004. Use of Caspian Sea water for Irrigiation, PhD Thesis, Tarbiat Modarres University, Iran (in Persian). 
Dordipour, I., 2000. An investigation on the suitability of using saline waters, Caspian water in particular for cotton irrigation. Special study, Soil Science Department, Faculty of Agriculture, Tarbiat Modarres University, Iran (in Persian).

El-Haddad, E. H. M., O’Leary, J. W., 1994. Effect of salinity and K/Na ratio of irrigation water on growth and solute content of Atriplex amnicola and sorghum bicolor. Irrigation Science 14, 127-133.

Feigin, A., 1985. Fertilization management of crops irrigated with saline water. Plant and Soil 82, 285-299.

Feigin, A., Pressman, E., Imas, P., and Miltau, O. 1991. Combined effects of $\mathrm{KNO}_{3}$ and salinity on yield and chemical composition of lettuce and Chinese cabbage. Irrigation Science 12, 223230.

Francois, L. E., Grieve, C. M., Mass, E. V., Lesch, S. M., 1994. Time of salt stress affects growth and yield components of irrigated wheat. Agronomy Journal 86, 100-107. Greenway. H., Munns, R., 1980. Mechanisms of salt tolerance in nonhalophytes. Annual Reviews in Plant Physiology. 31, 149-190.

Grieve, C.M., Lesch, S.M., Francois, L.E. and Maas, E.V. 1992. Analysis of main-stem yield components in salt-stresses wheat. Crop Science 32, 697-703.

Hamdy, A., Abdel- Dayem. S., Abu-zeid, M., 1993. Saline water management for optimum crop production. Agricultural Water Management 24, 189-203.

Hassan, N. A. K., Drew, V., Knudsen, D., Olson, R. A., 1970. Influence of soil salinity on production of dry matter and uptake and distribution of nutrients in barley and corn: 1.Barley (Hordeum Vulgare L.). Agronomy Journal 62, 43-45.

Helal, H.M. and Mengle, K. 1979. Nitrogen metabolism of young barley plants as affected by $\mathrm{NaCl}$ salinity and potassium. Plant and Soil 51, 547-562.

Homaee, M., 1999. Root water uptake under non-uniform transient salinity and water stress. Ph.D. Thesis, Wageningen Agricultural University, 173 p. 
Hu, Y. 1996. Growth response of wheat plant to salinity in hydroponics and soil. $\mathrm{PhD}$ dissertation, No. ETH 11619, Swiss Federal Institute of Technology, Zurich, Switzerland, 129p. Kwon, T.R., Harris, P.J.C. and Bourne, W.F. 2000. Salt-induced reduction of growth in Barssica rapa-L. Acta Hort 511, 157-164.

Marcelis, L. F. M., Van Hooijdonk, J., 1999. Effect of salinity on growth, water use and nutrient use in radish. Plant and Soil 215, 57-64.

Norlyn, J. D., Epstein, E., 1982. Barley production: Irrigation with sea water on coastal soil. Environmental Science Research 23, 525-529.

Page, A. L., Miller, R. H., Keeny, D. R., 1982. Methods of soil analysis. Part 2, 2nd ed. Agronomy Monograph 9, ASA and SSSA, Madison, WI , USA.

Qadir, M., Ghafoor, A. and Mortaza, G. 2001. Use of saline-sodic water through phytoremediation of calcareous saline-sodic soils. Agricultural Water Management 50, 229-241.

Rhoades, J. D., Bingham, F. T., Letey, J., Printer, P. J. Jr., Lament, R. D., Aleve, W, J., Hoffman, G. J., Replogle, J. A., Swain, R., Pacheco, P., 1980. Reuse of drainage water for irrigation, Soil salinity and water balance. Hilgardia 56, 17-44

Rhoades, J. D., Bingham. F. T., Letcy, J., Hoffman, G. J., Dedrick, A. R., Printer, P. J., Alves, W., Swain. R. Pacheco, P., Lemert, R., Replogle, J. A., 1989. Use of saline drainage water for irrigation: Imperial Valley study, Agricultural Water Management 16, 25-36.

Richards, L. A., 1954. Diagnosis and improvement of saline and alkali soils.USSL, USDA, Handbook 60, 160p.

SAS Institute., 1992. SAS/ STAT User`s guide: Statistics. Version 6.03, Cary, NC. USA.

Sharma, S.K. 1996. Soil salinity effect on transpiration and net photosynthetic rates, stomatal conductance. NaCl lents in durum wheat. Biologica Plantarum 38, 1257-1260.

Sparks, D. L., Page, A. L., Helmke, P. A., Loeppert, R. H., Soltanpour, P. N., 1996. Methods of Soil Analysis: Chemical methods. Part 3, No. 5. Book Series, Madison, WI: SSSA, ASA, USA. 
1 Tahir, O.A., Nabulsi, Y.A.A. and Helalia, A.M. 1997. Effect of water and frequency of irrigation

2 on growth and yield of barley (Hordeum vulgare L.). Agricultural Water Management 34,17-24.

3 Verma, T. S., Neue, H. U., 1984. Effect of soil salinity level and zinc application on growth,

4 yield, and nutrient composition of rice. Plant and Soil 82, 3-14.

5 Yazdani, H., 1991. Determination of salt tolerance in wheat varieties. Isfahan Agric. Res.

6 Centre, research report, (in Persian).

7 Zadoks, J. C., Chang, T. T., Konzak, C. F., 1974. A decimal code for growth stage of cereal, 8 Journal of Wheat Research 14, 415-421.

9 
2

\begin{tabular}{|lll|}
\hline Salt type & \% in Caspian Sea water & \% in Ocean water \\
\hline $\mathrm{NaCl}$ & 62.2 & 78.3 \\
$\mathrm{MgSO} 4$ & 23.6 & 6.40 \\
$\mathrm{MgCl} 2, \mathrm{MgBr} 2$ & 4.54 & 9.44 \\
$\mathrm{CaCO} 3$ & 1.24 & 0.21 \\
$\mathrm{KCl}$ & 1.21 & 1.69 \\
$\mathrm{CaSO} 4$ & 6.92 & 3.93 \\
\hline
\end{tabular}

3 
1 Table 2. Chemical characteristics of well and sea waters used in the experiments

2

\begin{tabular}{|c|c|c|c|}
\hline Property & Caspial & & Well water \\
\hline & Spring & Summer & \\
\hline ECe $(\mathrm{dS} / \mathrm{m})$ & 21.5 & 23.0 & 0.8 \\
\hline $\mathrm{pH}$ & 7.3 & 7.0 & 7.5 \\
\hline $\mathrm{Cl}$ (mmoles_/l) & 180 & 165 & 2 \\
\hline $\mathrm{HCO}_{3}$ (mmoles_/l) & 2.0 & 3.6 & 2.7 \\
\hline $\mathrm{SO}_{4}$ (mmoles_/l ) & 58.0 & 67.0 & 3.2 \\
\hline Sodium $\left(\mathrm{mmoles}_{+} / \mathrm{l}\right)$ & 160 & 150 & 2 \\
\hline Calcium (mmoles+/l ) & 80 & 68 & 5 \\
\hline Magnesium (mmoles + /l) & 0 & 18 & 1 \\
\hline
\end{tabular}

3 
1 Table 3: Some physical and chemical characteristics of the soils used in pot and field

2 experiments

3

\begin{tabular}{|lll|}
\hline Property & Soil used in pot experiment & Field soil \\
\hline EC $(\mathrm{dS} / \mathrm{m})$ & 16.1 & 10 \\
$\mathrm{pH}$ & 7.75 & 8.1 \\
$\mathrm{CEC}(\mathrm{Cmol} / \mathrm{kg})$ & 10 & 13 \\
$\mathrm{SP}(\%)$ & 38.5 & 43 \\
Exchangeable $\mathrm{Na}^{+1}(\mathrm{cMol} / \mathrm{kg})$ & 2.8 & 3.1 \\
Exchangeable $\mathrm{Ca}^{+2}(\mathrm{cMol} / \mathrm{kg})$ & 6 & 7.9 \\
Exchangeable $\mathrm{Mg}^{+2}(\mathrm{cMol} / \mathrm{kg})$ & 1.1 & 2 \\
Bulk density $\left(\mathrm{kg}^{2} \mathrm{~m}^{3}\right)$ & 1450 & 1540 \\
Texture & Silt loam & Silt loam \\
\hline
\end{tabular}

4 


\begin{tabular}{|c|c|c|c|}
\hline \multirow[t]{2}{*}{ Yield \& yield components } & \multicolumn{3}{|c|}{ Irrigation treatments } \\
\hline & $\overline{\mathrm{I}_{0}}$ & $\overline{\mathrm{I}_{1}}$ & $\mathrm{I}_{2}$ \\
\hline Yield (g/pot) & $23.06 \mathrm{~A}^{*}$ & $8.71 \mathrm{~B}$ & $22.26 \mathrm{~A}$ \\
\hline Seed No (per head) & $22.97 \mathrm{~B}$ & $17.99 \mathrm{C}$ & $24.49 \mathrm{~A}$ \\
\hline SW 100 (g) & $3.85 \mathrm{~A}$ & $2.62 \mathrm{~B}$ & $3.83 \mathrm{~A}$ \\
\hline Head No (per pot) & $33.48 \mathrm{~A}$ & $20.63 \mathrm{~B}$ & $31.37 \mathrm{~A}$ \\
\hline Sterile shoot No (per pot) & $10.82 \mathrm{~A}$ & $3.44 \mathrm{~B}$ & $8.89 \mathrm{~A}$ \\
\hline Spikelet No (per head) & $10.18 \mathrm{~A}$ & $8.26 \mathrm{~B}$ & $10.45 \mathrm{~A}$ \\
\hline Hallow heads (\%) & $24.89 \mathrm{AB}$ & $27.68 \mathrm{~A}$ & $21.90 \mathrm{~B}$ \\
\hline Dry head weight (g/pot) & $27.22 \mathrm{~A}$ & $10.95 \mathrm{~B}$ & $26.54 \mathrm{~A}$ \\
\hline Dry leaf weight (g/pot) & $8.59 \mathrm{~A}$ & $4.66 \mathrm{C}$ & $7.75 \mathrm{~B}$ \\
\hline Dry shoot weight (g/pot) & $17.72 \mathrm{~A}$ & $6.59 \mathrm{C}$ & $16.45 \mathrm{~B}$ \\
\hline Dry root weight (g/pot) & $5.49 \mathrm{~A}$ & $1.27 \mathrm{C}$ & $3.53 \mathrm{~B}$ \\
\hline
\end{tabular}


1 Table 5. Chemical characteristics of soil before and after pot experiments

2

\begin{tabular}{|llll|}
\hline Property & Soil before & Soil after & Soil after \\
& experiment & experiment & experiment \\
& & $(0-10 \mathrm{~cm})$ & $(10-25 \mathrm{~cm})$ \\
\hline ECe $(\mathrm{dS} / \mathrm{m})$ & 16.19 & 1024 & 143 \\
\hline Sodium Adsorption Ratio & 19 & 689 & 59 \\
\hline Sodium (mmoles $/ \mathrm{l})$ & 112 & 48503 & 315 \\
\hline Calcium $(\mathrm{mmoles}+\mathrm{l})$ & 39 & 676 & 808 \\
\hline Magnesium (mmoles $+\mathrm{l})$ & 29 & 5556 & 1094 \\
\hline Potassium (mg/kg) & 240 & 23109 & \\
\hline
\end{tabular}

3 
1 Figure captions

$2 \quad$ Fig 1: Pot experiments in the greenhouse

$3 \quad$ Fig 2: $\quad$ Plot experiments at Gorgan Experimental Station

4 Fig 3: Effect of irrigation regimes on the yield and yield components of barley in pot experiments

$6 \quad$ Fig 4: Effect of irrigation regimes on dry/fresh weight of leaf, head, shoots and areal biomass 7 in pot experiments

$8 \quad$ Fig. 5: Variation of root parameters with irrigation regime and soil depth

9 Fig 6: Effect of irrigation regime on yield and yield components of barley in field plot experiments

11 Fig 7. Effect of irrigation regime on the electrical conductivity of soil in pot experiments

Fig 8: Effect of irrigation regime on soil salinity and the SAR of its saturation extract 
$1 \quad$ Fig 1

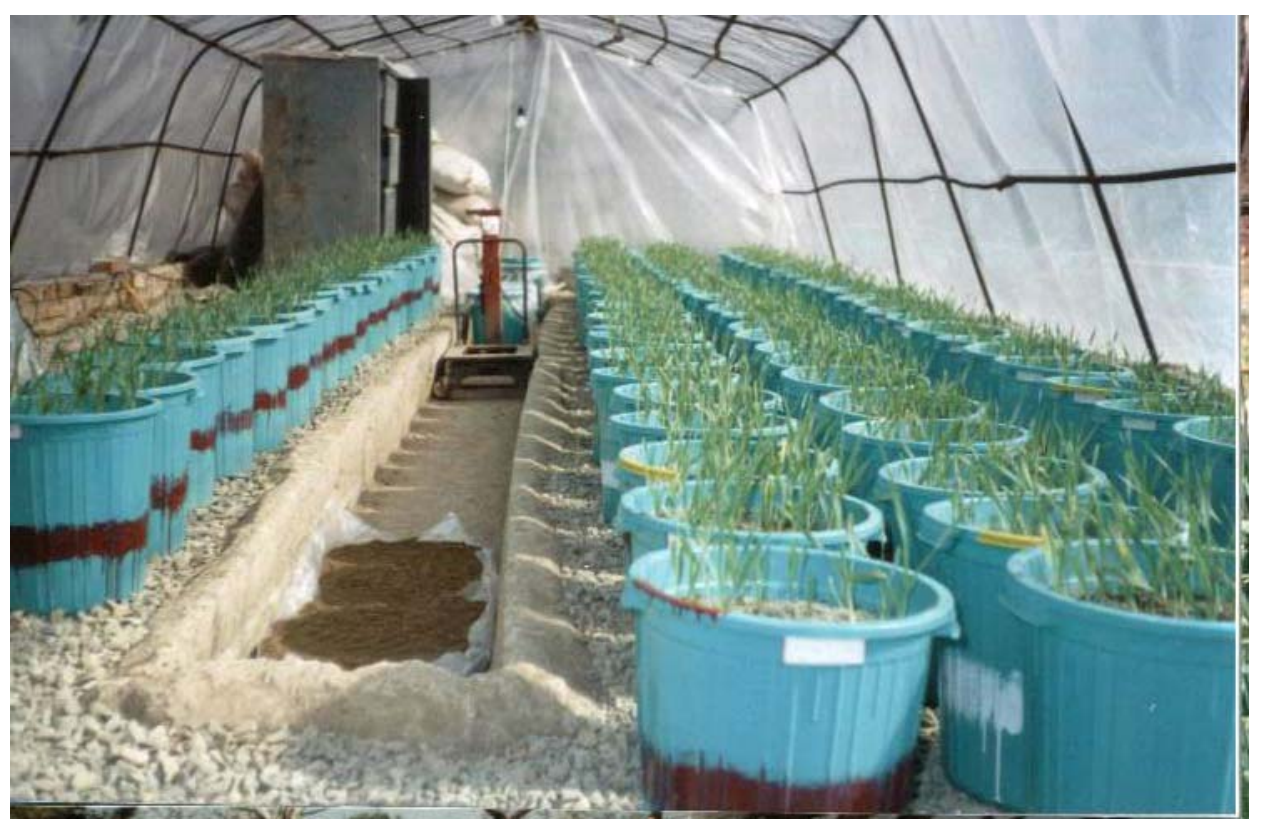

2

3 
$1 \quad$ Fig 2

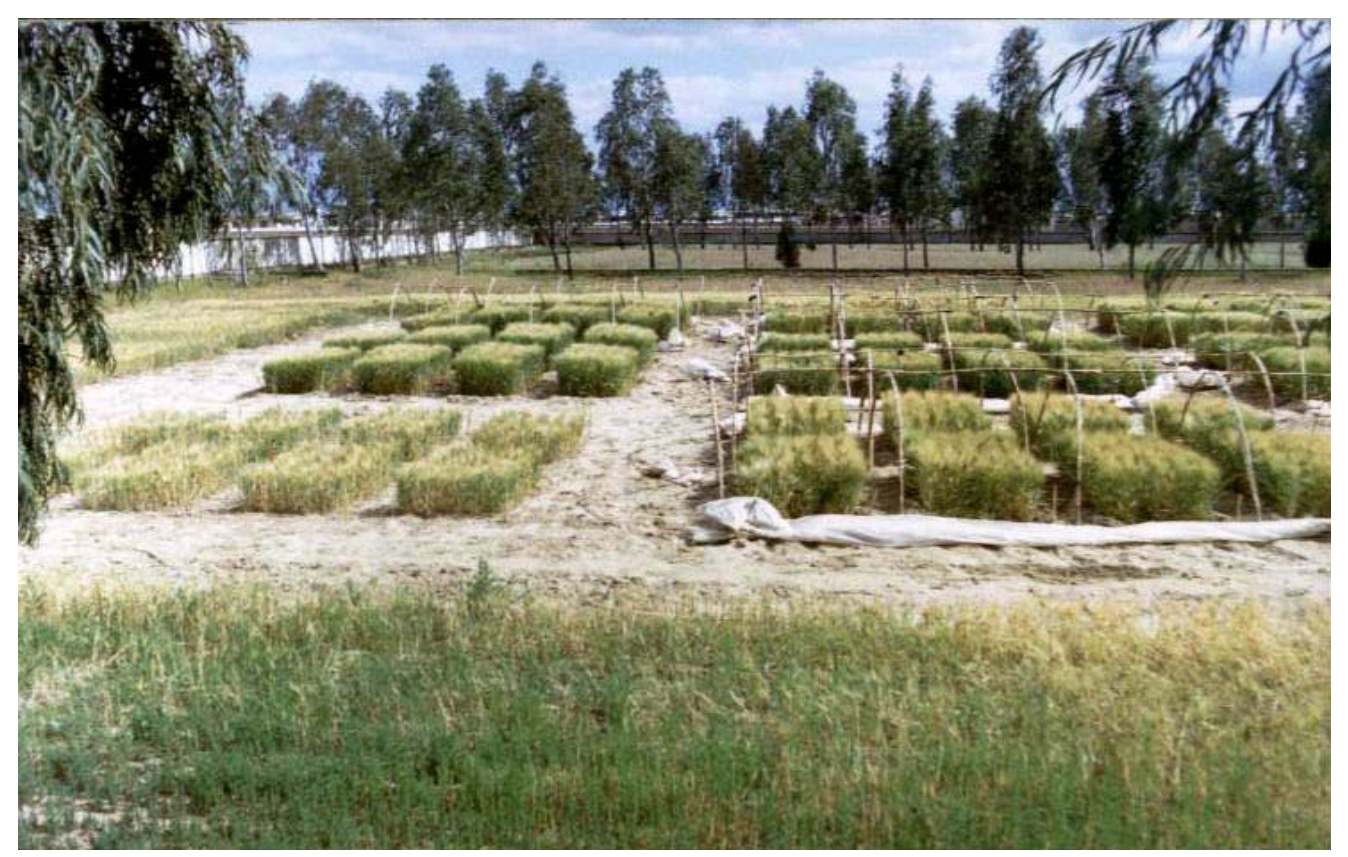


Fig 3

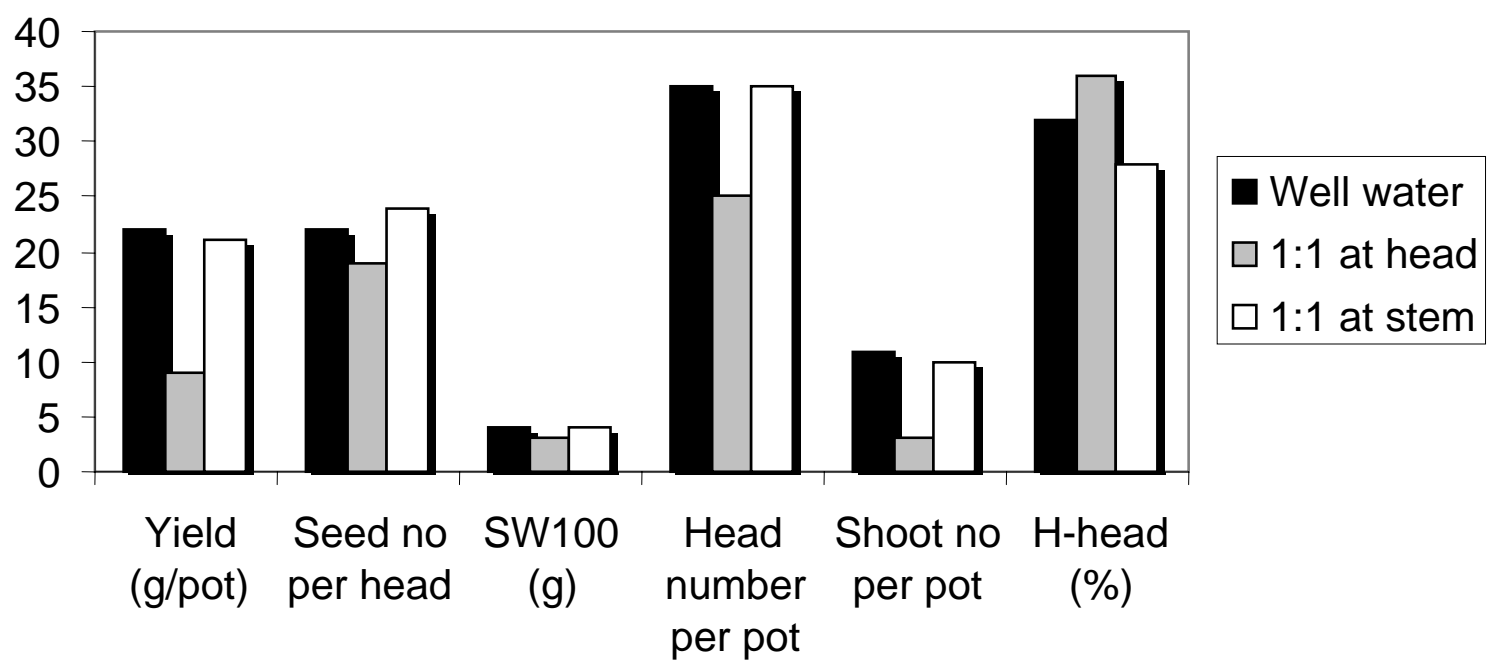


$1 \quad$ Fig 4

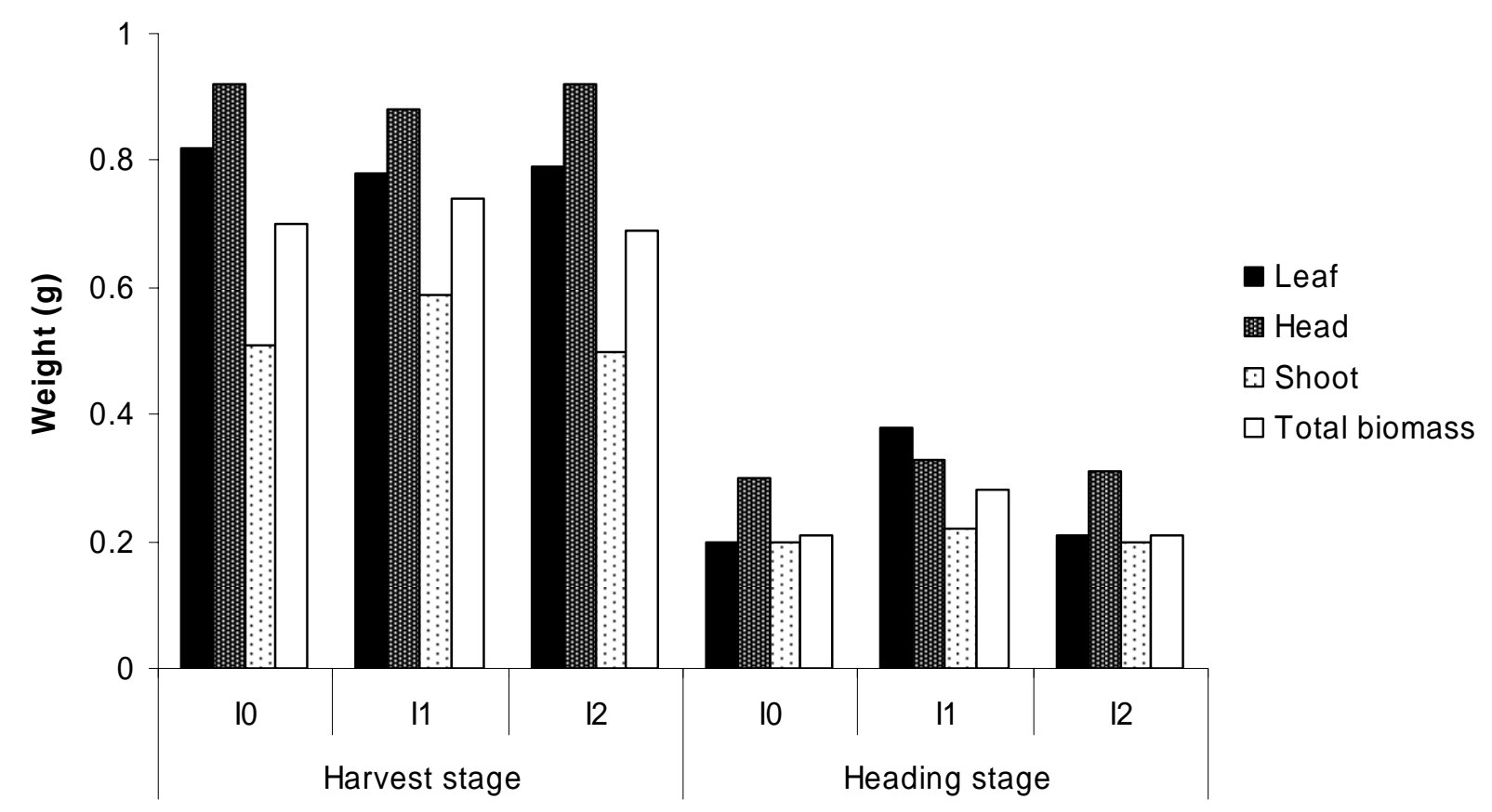


Fig 5

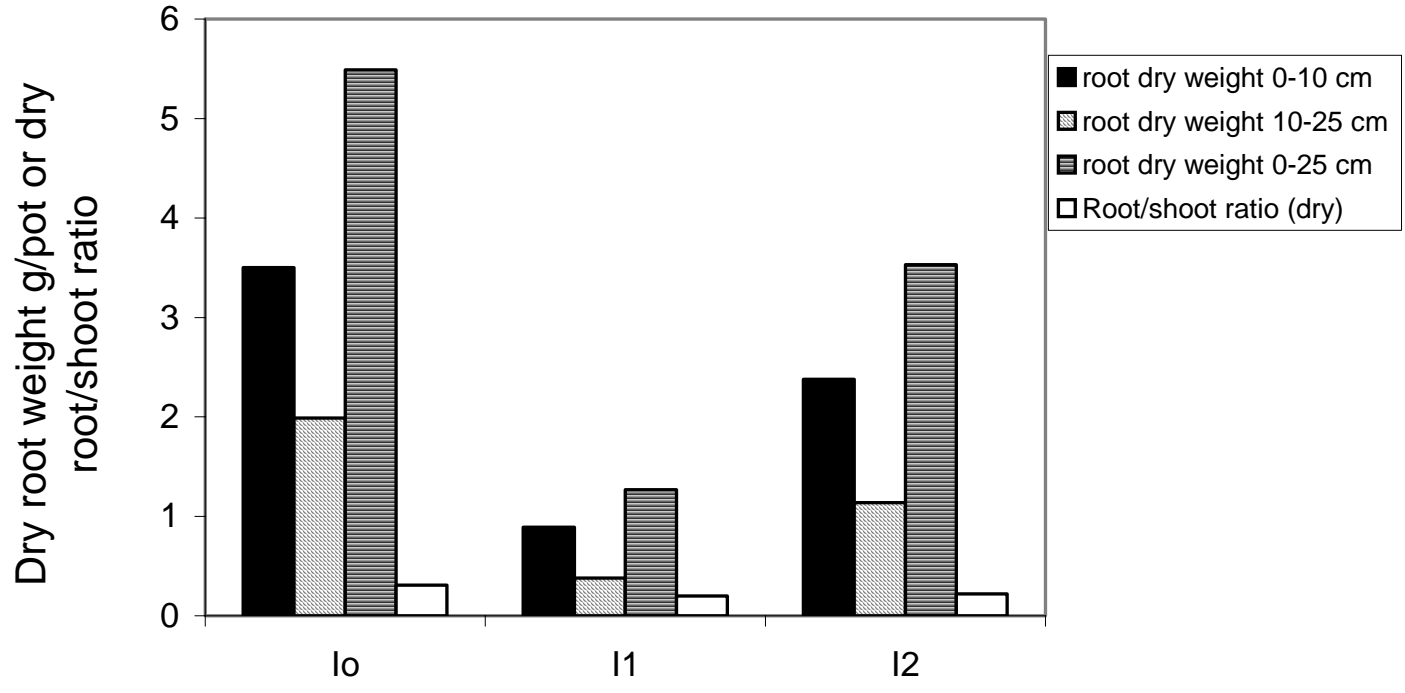

Irrigation regime 
1

Fig 6

2

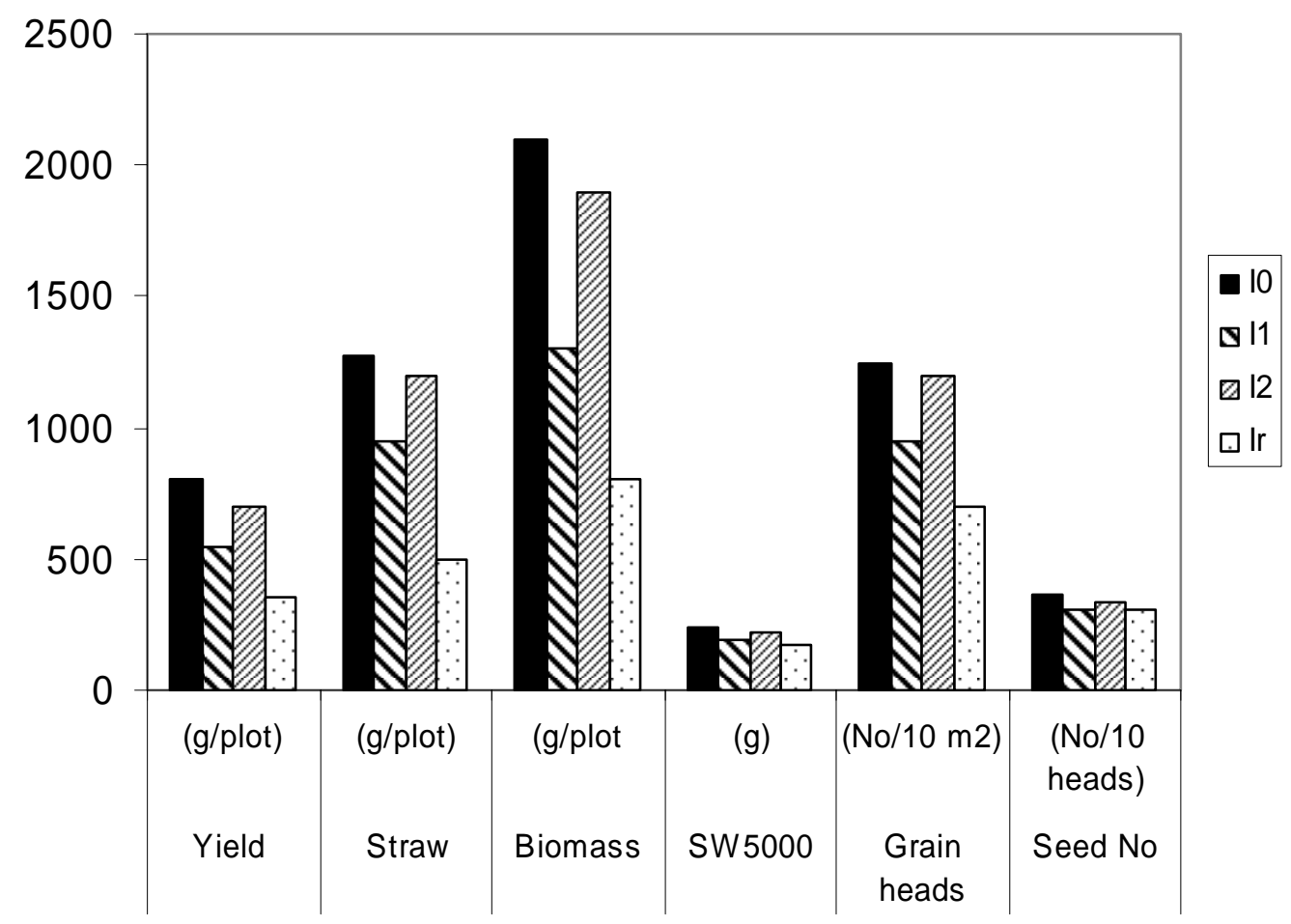


$1 \quad$ Fig 7

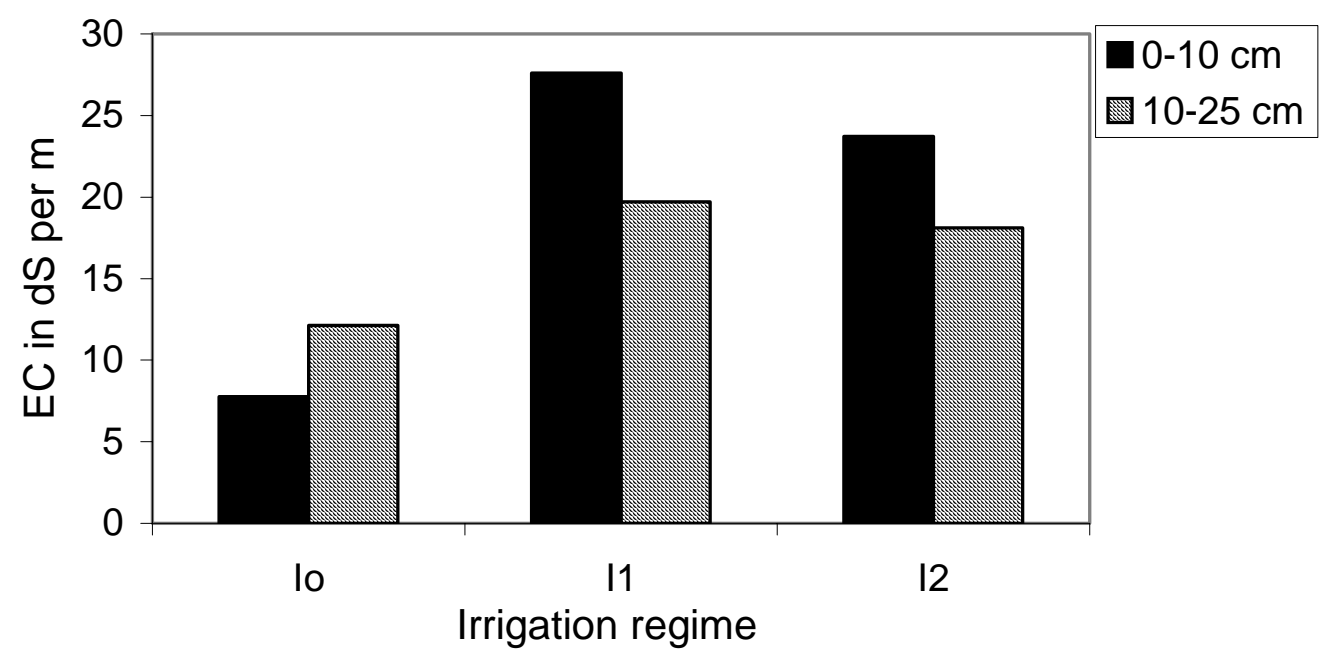

2 
$1 \quad$ Fig 8

2

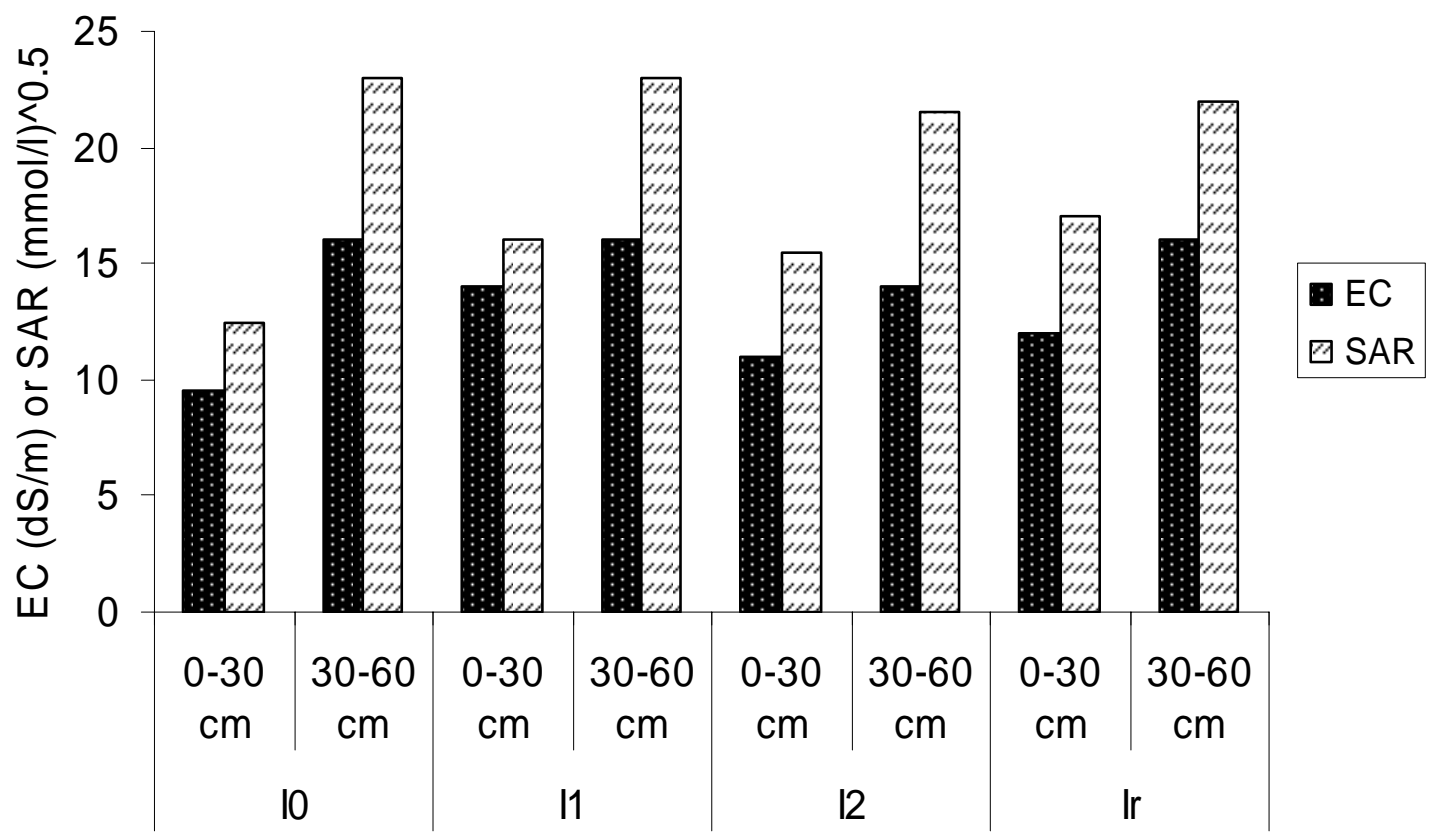

